\title{
An attempt to devise a skin test for regional enteritis
}

\author{
R. C. SANDERS \\ From Oxford University Clinical School
}

EDITORIAL SYNOPSIS This is a preliminary report on an attempt to devise a skin test analagous to the Kveim test. Although at present negative it is clearly a line which needs further study.

The aetiology of regional enteritis is unknown but its histological similarity to sarcoidosis has often been described (Hadfield, 1939). The Mantoux reaction is $70 \%$ negative in sarcoidosis (James, 1956), and the same low response rate has been reported in regional enteritis (Blackburn, Hadfield, and Hunt, 1939; Phear, 1958). These similarities provided the rationale for an attempt to devise a skin test for regional enteritis analogous to the Kveim test for sarcoidosis. The Kveim test consists of the intradermal injection of a lymph node extract obtained from an active sarcoid lesion. If the test is positive, a sarcoid plaque develops between one and six weeks later at the site of the injection (Siltzbach and Ehrlich, 1954). James and his colleagues have recently reported a large series showing that the test is almost specific for sarcoidosis, and is positive in $64 \%$ of histologically proven cases (Anderson, James, Peters, and Thomson, 1963).

\section{METHOD}

MATERIAL The material was prepared from terminal ileum resected from a patient with regional enteritis. Enlarged lymph nodes adjacent to the affected area were excised, placed in normal saline, and stored at $20^{\circ} \mathrm{C}$. The resected ileum and lymph nodes presented the histological appearance of regional enteritis with giant cells but 'no clearly defined giant cell granulomata'.

Preparation of the material The lymph nodes were thawed and disintegrated in a mechanical disintegrator under sterile conditions. Nine volumes of saline were added to one volume of tissue; this mixture was filtered through sterile gauze to remove gross particles. The filtrate was heated in a water bath at $60^{\circ} \mathrm{C}$. for two hours, allowed to stand at room temperature for 24 hours, and then heated again at $60^{\circ} \mathrm{C}$. for two hours. No growth was obtained on aerobic and anaerobic culture. Finally, for injection, an equal volume of sterile saline containing $0.5 \%$ phenol was added.

PATIENTS STUDIED A search was made of the hospital notes of all patients at the Radcliffe Infirmary with a diagnosis of regional enteritis. Nine patients who had had the diagnosis confirmed at operation, with lesions confined to the terminal ileum, were selected. All lived in Oxford. Four had active lesions; activity was judged present if at least two of the following criteria were recorded: $1 \mathrm{~A}$ high E.S.R.; 2 a radiograph suggestive of persistent disease; 3 symptoms of abdominal pain and loss of weight. All four patients were on prednisolone in doses ranging from 5 to $20 \mathrm{mg}$. a day. Nine controls were matched for age and sex; they consisted of two medical students, a doctor, four patients in the accident wards, and two patients with myocardial infarction.

MODE OF INJECTION Of the extract, $0 \cdot 1-0 \cdot 2 \mathrm{ml}$. was injected intradermally into the flexor surface of both forearms with a Mantoux syringe and needle.

FOLLOW-UP The size and appearance of any response was noted at 24 hours and at later dates, depending on how the lesion was progressing. Any systemic effects were recorded. Skin biopsy was performed on four patients.

\section{RESULTS}

The results do not show a strikingly different response between the patients with regional enteritis and the controls (Table I).

The typical history of the lesion was the appearance, within a matter of hours, of an area of diffuse erythema, without induration, around the site of the injection. Slightly later, but still within hours, a hard, raised, painless, papule, usually $5 \mathrm{~mm}$. in diameter, developed at the injection site. The erythema usually vanished within 24 hours but the papule generally persisted. Biopsy was performed at varying intervals on four of the regional enteritis patients. On each occasion the histological picture was that of a non-specific inflammatory response compatible with the injection of foreign protein.

A papule persisting three weeks occurred in a patient with active regional enteritis placed on prednisolone three days after the extract was injected. However, biopsy at two weeks showed a non- 
TABLE I

COMPARISON OF RESULTS IN PATIENTS WITH REGIONAL ENTERITIS AND CONTROLS

No Reaction

Papules Lasting

Papules Lasting
Four to Five Days

Papules Lasting

Total Less than Four Days Four to Five Days More than

Three Weeks

\begin{tabular}{llllll}
\hline Controls & 2 & 3 & 2 & 2 & 9 \\
$\begin{array}{l}\text { Patients with } \\
\text { regional enteritis }\end{array}$ & 2 & 2 & 4 & 1 & 9
\end{tabular}

specific histological response. One result of possible significance is that of a patient whose papule reappeared on two subsequent occasions at weekly intervals. Unfortunately, it was not practicable to biopsy this lesion.

\section{DISCUSSION}

These results suggest that a skin response analogous to the Kveim reaction does not occur in regional enteritis when lymph node extract obtained from a patient with regional enteritis is injected intradermally. A similar reaction to the test material took place in patients and controls. Biopsy at varying time intervals after the material was injected showed only the expected response to foreign material.

It is possible that the lymph node extract may not have been active; it is well known that in the Kveim test only two-thirds of the extracts are potent (Siltzbach and Ehrlich, 1954). The histological appearance of the resected lymph nodes from which the extract was prepared corresponded with the 'diffuse granulomatous' picture described by Williams (1963) who has correlated the Mantoux response with different histological appearances in patients with regional enteritis. Possibly material obtained from a patient whose ileum had a histological picture that fitted one of his other categories might have produced a positive response. Undoubtedly there would have been a greater likelihood of a potent extract if tissue from several cases of regional enteritis had been mixed but this was thought unjustifiable in view of the increased risk of serum jaundice.

There are two other possible causes of failure to obtain a positive response. Four of the patients with regional enteritis were on corticosteroid treatment which may have inhibited any response, as is known to happen in the Kveim reaction (Anderson et al., 1963). Furthermore the activity of the disease varied and the four patients with unequivocal evidence of active disease were all being treated with corticosteroids.

I am indebted to Mr. A. Elliott-Smith for the removal of the lymph nodes, to Dr. R. L. Vollum for the preparation of the material, to Dr. D. Richards for examining the biopsy material, and to Professor L. J. Witts and the consultants at the Radcliffe Infirmary who gave me access to their patients. I am particularly grateful to Drs. E. D. Acheson, R. Wright, and T. E. Lovell for their support and advice.

\section{REFERENCES}

Anderson, R., James, D. G., Peters, P. M., and Thomson, A. D (1963). The Kveim test in sarcoidosis. Lancet, 2, 650-653.

Blackburn, G., Hadfield, G., and Hunt, A. H. (1939). Regional ileitis. St. Bart's Hosp. Rep., 72, 181-224.

Hadfield, G. (1939). The primary histological lesion of regional ileitis. Lancet, 2, 773-775.

James, D. G. (1956). Diagnosis and treatment of sarcoidosis. Brit. med. J., 2, 900-904.

Phear, D. N. (1958). The relation between regional ileitis and sarcoidosis. Lancet, 2, 1250-1251.

Siltzbach, L. E., and Ehrlich, J. C. (1954). The Nickerson-Kveim reaction in sarcoidosis. Amer. J. Med., 16, 790-803.

Williams, W. J. (1963). The laboratory diagnosis of Crohn's syndrome. Proc, roy. Soc. Med., 56, 490. 